Check for updates

Cite this: RSC Adv., 2018, 8, 24750

\title{
Hematite iron oxide nanoparticles: apoptosis of myoblast cancer cells and their arithmetical assessment $\uparrow$
}

\author{
Rizwan Wahab, (D) *ab Farheen Khan ${ }^{\star c}$ and Abdulaziz A. Al-Khedhairy ${ }^{a}$
}

Hematite $\left(\alpha-\mathrm{Fe}_{2} \mathrm{O}_{3}\right)$ forms iron oxide nanoparticles (NPs) which are thermally stable and have various electrochemical and optochemical applications. Due to their wide applicability, the present work was designed to form the hematite phase of iron oxide $\left(\alpha \mathrm{Fe}_{2} \mathrm{O}_{3} \mathrm{NPs}\right) \mathrm{NPs}$ prepared via a solution process. Their cytological performance was checked with $\mathrm{C} 2 \mathrm{C} 12$ cells. The crystalline property of the NPs was examined with X-ray diffraction patterns (XRD) and it was found that the size of the particles formed ranged from 12 to $15 \mathrm{~nm}$. Structural information was also identified via field emission scanning electron microscopy (FESEM) and transmission electron microscopy (TEM), which again confirmed that the size of each NP is about 12-15 $\mathrm{nm}$. Surface topographical analysis was done via atomic force microscopy (AFM), which reveals that the size of the distance between two particles is in the range of $12 \pm 3 \mathrm{~nm}$. The $\mathrm{C} 2 \mathrm{C} 12$ cells were cultured in a humidified environment with $5 \% \mathrm{CO}_{2}$ and were checked via a microscope. The $\alpha \mathrm{Fe}_{2} \mathrm{O}_{3} \mathrm{NPs}$ were used for cytotoxic evaluation against C2C12 cells. A MTT (3-(4,5-dimethyl thiazol-2-yl)-2,5-diphenyltetrazolium bromide) assay was utilized to check the viability of cells in a dose-dependent (100 ng mL $\mathrm{mL}^{-1}, 500 \mathrm{ng} \mathrm{mL}^{-1}$ or $1000 \mathrm{ng} \mathrm{mL}^{-1}$ ) manner. The morphology of the cells under the influence of $\alpha \mathrm{Fe}_{2} \mathrm{O}_{3} \mathrm{NPs}$ for live and dead cells in a wet environment was confirmed via confocal laser scanning microscopy (CLSM). The apoptosis caused due to the $\alpha \mathrm{Fe}_{2} \mathrm{O}_{3} \mathrm{NPs}$ was evaluated in presence of caspases 3/7 with GAPDH genes, which confirmed the upregulation that is responsible in caspase 3/7 genes, with treatment of $\mathrm{C} 2 \mathrm{C} 12$ at low $\left(500 \mathrm{ng} \mathrm{mL}^{-1}\right.$ ) and high (1000 ng $\mathrm{mL}^{-1}$ ) doses of $\alpha \mathrm{Fe}_{2} \mathrm{O}_{3} \mathrm{NPs}$. Analytical studies were also performed to authenticate the obtained data for $\alpha \mathrm{Fe}_{2} \mathrm{O}_{3} \mathrm{NPs}$ using parameters such as precision, accuracy, linearity, limits of detection (LOD) and limit of quantitation (LOQ), quantitative recoveries and relative standard deviation (RSD). The analyses play a significant role in investigating the large effect of $\alpha \mathrm{Fe}_{2} \mathrm{O}_{3} \mathrm{NPs}$ on $\mathrm{C} 2 \mathrm{C} 12$ cells.

Received 26th March 2018 Accepted 9th June 2018

DOI: $10.1039 / c 8 \mathrm{ra02613k}$

rsc.li/rsc-advances sorbants, ${ }^{13}$ electrode materials, ${ }^{\mathbf{1 4}}$ lithium ion battery electrodes, ${ }^{15}$ and storage materials. ${ }^{16}$ The low band gap enables greater possibility for the absorption of light in the visible range compared to $\mathrm{TiO}_{2} \mathrm{NPs}^{17}$ Various ways have been adopted to prepare different types of iron oxide NPs, such as sol-gel, ${ }^{18}$ surfactant assisted, ${ }^{19}$ hydrothermal, ${ }^{20}$ thermal oxidation, ${ }^{21}$ microwave, ${ }^{22}$ mechanical milling etc. ${ }^{23}$ Hematite nanostructures can be synthesised with various physicochemical parameters by changing their size, precursor concentration, the $\mathrm{pH}$ of the solution, surface properties etc $^{\mathbf{2 4}}$. Several researchers have drawn attention to this direction, such as Lassoued et al. who described the effect of a change in concentration of the precursor solution on the formation of hematite nanoparticles, checking the size of the nanoparticles, their morphology and optical properties, ${ }^{25}$ whereas in another report, the sizes of the nanoparticles were varied by heating, when they formed different phases of iron, $\left(\gamma-\mathrm{Fe}_{2} \mathrm{O}_{3}\right)$ or $\left(\alpha-\mathrm{Fe}_{2} \mathrm{O}_{3}\right) \cdot{ }^{26}$ Hematite nanoparticles $\left(\alpha-\mathrm{Fe}_{2} \mathrm{O}_{3}\right)$ can also be synthesised via controlled precipitation methods with variation in the precursor's precipitation methods using inorganic metal salts or washing the material, and calcination also affected the size of the 
nanostructures. This is dependent upon the synthetic method adopted and their processes can be optimized to develop highquality nanoparticles. ${ }^{27}$ The size distribution also changes with a variation in $\mathrm{pH}$ and has the property of forming $\alpha-\mathrm{Fe}_{2} \mathrm{O}_{3} \mathrm{NPs}{ }^{28}$ Preparation at low cost, with good quality, via a facile approach is a challenging task that can be met via a solution process. Considering the physical, optical and chemical applications of hematite $\left(\alpha-\mathrm{Fe}_{2} \mathrm{O}_{3}\right)$ NPs, they have been utilized as biomedical materials in drug delivery, chemotherapy, MRI, antibacterial agents etc. The magnetic nanoparticles can be functionalized with various biological molecules, such as proteins or nucleic acids, via physicochemical conjugations. ${ }^{29,30}$ The magnetic NPs $\left(\alpha-\mathrm{Fe}_{2} \mathrm{O}_{3}\right)$ have an excellent biocompatibility and thus could be used in many in vitro and in vivo imaging studies. ${ }^{31}$

For various physicochemical applications of hematite $(\alpha$ $\left.\mathrm{Fe}_{2} \mathrm{O}_{3}\right)$ NPs, very limited information is available about using nanostructures as anticancer agents. To control the proliferation rate of cancer cells and to understand their role, researchers have utilized nanostructures against cancer cells. For example, $30 \mathrm{~nm}$ size NPs were exploited as an anticancer agent against lung cancer cells (HepG2) in a dose-dependent manner. ${ }^{32}$ In another report, magnetic NPs work in long-term corresponding imaging, in modalities and transplanted cells which could be used in MRI or CT in preclinical animal models. $^{33}$ Among these NPs, the core-shell shaped nanostructures of hematite (thickness $\sim 10-20 \mathrm{~nm}$, diameter $\sim 80$ $100 \mathrm{~nm}$ ) embedded with plate-like structures exhibit low cytotoxicity levels on human lung fibroblast (MRC5) cell lines for biomedical applications. ${ }^{34}$ The hematite $\left(\alpha-\mathrm{Fe}_{2} \mathrm{O}_{3}\right)$ nanoparticles were utilized on the Madin-Darby Canine Kidney (MDCK) cell line to find out the degree of internalization into the cells, generating free radical species which influence the cytotoxic effects. ${ }^{35}$ The $\alpha-\mathrm{Fe}_{2} \mathrm{O}_{3}$ nanoparticles were also utilized to check their cytotoxic influence on human breast cancer MCF7 cells. $^{36}$ Recent advances demonstrate that magnetic nanoparticles have the ability to work as drug delivery systems, and to deliver the NPs to the cells and specified organs. Rat stem cells were magnetized and the iron oxide NPs were used on the upper hemisphere of a rodent retina. ${ }^{37}$

The present work demonstrates the utilization of chemically synthesized hematite $\left(\alpha-\mathrm{Fe}_{2} \mathrm{O}_{3}\right)$ for its potential cytological effect on myoblast (C2C12) cancer cells, which has not yet been explored under in vitro conditions. The crystalline character of the NPs was examined by looking at the XRD pattern, whereas the morphology of the NPs was evaluated via FESEM and TEM. The topographical evaluation was completed with AFM. The \% cell viability was examined with an MTT assay in a dosedependent manner and the morphological changes in cells were studied via inverted microscopy. Cell death with a dosedependent incorporation of hematite $\left(\alpha-\mathrm{Fe}_{2} \mathrm{O}_{3}\right)$ NPs in a wet environment was also checked with CLSM. Apoptosis in cells with NPs and their genetic study were performed with caspases 3 and 7 with GAPDH genes. The acquired data was validated with statistical analytical parameters such as precision, accuracy, linearity, limits of detection (LOD) and limit of quantitation (LOQ), quantitative recoveries and relative standard deviation (RSD).

\section{Materials and methods}

\section{Experimental}

Synthesis of iron oxide $\left(\alpha \mathrm{Fe}_{2} \mathrm{O}_{3} \mathrm{NPs}\right)$ nanoparticles. The synthesis of iron oxide $\left(\alpha \mathrm{Fe}_{2} \mathrm{O}_{3}\right.$ NPs, hematite phase) NPs was accomplished using iron(III) nitrate nonahydrate $\left(\mathrm{Fe}\left(\mathrm{NO}_{3}\right)_{3} \cdot 9 \mathrm{H}_{2} \mathrm{O}\right)$, $n$-propylamine $\left(\mathrm{CH}_{3}-\left(\mathrm{CH}_{2}\right)_{2}-\mathrm{NH}_{2}\right)$ and sodium hydroxide $(\mathrm{NaOH})$. The chemicals for the preparation of the NPs were purchased from the Aldrich Chemical Corporation (U.S.A) and used without further purification. In a typical experiment: $\mathrm{Fe}\left(\mathrm{NO}_{3}\right)_{3} \cdot 9 \mathrm{H}_{2} \mathrm{O}\left(3 \times 10^{-2} \mathrm{M}\right)$ and $n$-propyl amine $(\sim 20 \%)$ were mixed in methanol $(\mathrm{MeOH})$ under constant stirring, and after mixing a brown-colored solution appeared in the beaker. Into this colored solution, $\mathrm{NaOH}(0.1 \mathrm{M})$, was mixed and shaken each time for complete mixing. After the complete addition, the $\mathrm{pH}$ of the solution was checked via a $\mathrm{pH}$ meter (Cole Parmer, U.S.A.). Due to the increase in basicity of the solution, the $\mathrm{pH}$ reached 12.06. After complete mixing, the solution was transferred to a two-necked glass pot and was heated at $\sim 90{ }^{\circ} \mathrm{C}$ for an hour (h). During this experiment, as the solution temperature rises, the color of the solution changes to dark brown. When the reaction process was complete, the product was separated by centrifugation ( $3000 \mathrm{rpm} \mathrm{min}^{-1}$ for $5 \mathrm{~min}$ ), and washed repeatedly with $\mathrm{MeOH}$, ethanol and acetone to remove the chemical impurities. The obtained powdery material was dried at room temperature to avoid agglomeration of the particles. The dried NPs were further utilized for chemical, morphological and biological studies.

\section{Characterization}

The prepared NPs were analysed in terms of their morphological, chemical and topographical properties. The morphological observations of the prepared nanopowders were made by FESEM (Hitachi S-4700, Japan) and TEM (JEOL JEM JSM 2010, Japan). Apart from these characterizations, AFM was also utilized to check the surface topographical behaviour (horizontal, vertical and lateral size of grown NPs). For AFM (Veeco, USA) observations, the sample was prepared on the silicon substrate by dropping an liquid dispersion of NPs and dried at room temperature for about $30 \mathrm{~min}$. The crystallinity, phases and size of the prepared powder was characterized by XRD with $\mathrm{Cu}_{\mathrm{K} \alpha}$ radiation $(\lambda=1.54178 \AA$, Rigaku, Japan) in the range of $20-80^{\circ}$ with a $6^{\circ} \mathrm{min}^{-1}$ scanning speed with $40 \mathrm{kV}$ and $30 \mathrm{~mA}$ current. Fourier transform infrared spectroscopy (FTIR, PerkinElmer GX spectrophoto meter) measurements were analysed in the range $4000-400 \mathrm{~cm}^{-1}$.

\section{Cell culture}

The cancer cells (C2C12) were purchased from the American Type Culture collection (ATCC-CRL 1772; Bethesda, MD) and cultured in growth medium (Dulbecco's Modified Eagle's Medium, DM EM), which contains $10 \%$ fetal bovine serum (FBS), $100 \mathrm{IU} \mathrm{mL} \mathrm{m}^{-1}$ penicillin, and $100 \mu \mathrm{g} \mathrm{mL} \mathrm{m}^{-1}$ streptomycin and incubated in a humidified incubator at $37{ }^{\circ} \mathrm{C}$ with $5 \% \mathrm{CO}_{2}$. The medium was changed every alternate day and the cells were subcultured with trypsin after they had passed 50-70\% confluence. 


\section{Cell viability by MTT assay}

The viability of the cells was checked with cell proliferation kit I (MTT (3-(4,5-dimethylthiazol-2-yl)-2,5-diphenyltetrazolium bromide), a tetrazole, provided by ROCHE, Ltd, U.S.A.) according to the manufacturer's instructions. Briefly, the cell line was seeded into 96 -well plates at $5 \times 10^{3}$ cells per well and the plate incubated overnight at $37^{\circ} \mathrm{C}$ in a humidified incubator with $5 \%$ $\mathrm{CO}_{2}$. The $\mathrm{C} 2 \mathrm{C} 12$ cells were incubated with different concentration (100 ng mL ${ }^{-1}, 500 \mathrm{ng} \mathrm{mL}^{-1}$ and $1000 \mathrm{ng} \mathrm{mL}{ }^{-1}$ ) of $\alpha \mathrm{Fe}_{2}-$ $\mathrm{O}_{3}$ NPs and returned to the incubator for $24 \mathrm{~h}, 48 \mathrm{~h}$ and $72 \mathrm{~h}$. The cytotoxic assessment or mitochondrial dysfunction was evaluated by the use of MTT $(\sim 10-20 \mu \mathrm{L}$ added to each well and kept for $\sim 3 \mathrm{~h}$ ) salt/assays. The MTT salt reduces to form a purple formazan salt in the mitochondria of living cells. The stored stock MTT solution was added to the control and treated with NPs, and the cell samples were again incubated at $37^{\circ} \mathrm{C}$ for $4 \mathrm{~h}$. After the incubation, the samples were removed from the incubator and mixed with solublizing buffer (DMSO, $100 \mu \mathrm{L}$ per well) solution. A purple color was visible at this stage, which deepened with pipetting. The control and treated samples were again incubated overnight to ensure that the formazan precipitate had dissolved. The measurement of the MTT assay was analyzed with an Elisa Reader (Bio Rad) at $570 \mathrm{~nm}$. The UVirradiation was provided by a deuterium and xenon lamp. The absorbances of the colored solutions were recorded at $570 \mathrm{~nm}$ by a spectrophotometer. The percentage (\%) viability was calculated as follows:

$$
\begin{aligned}
\% \text { Viability }= & \text { OD }(\text { optical densities }) \text { in sample well/ } \\
& \text { OD in control well } \times 100
\end{aligned}
$$

\section{Confocal scanning laser microscopy (CSLM) measurement}

To find the dose-dependent cell deaths in a wet environment with prepared NPs, the cells (C2C12) were cultured and seeded $\left(5 \times 10^{3}\right.$ cell per well $)$ into a confocal disk. The cells with $\alpha \mathrm{Fe}_{2} \mathrm{O}_{3} \mathrm{NPs}$ were incubated $(24 \mathrm{~h})$ at $37{ }^{\circ} \mathrm{C}$ in a humidified environment with $5 \% \mathrm{CO}_{2}$. When the cells passed $50-70 \%$ confluence, the medium was removed from the confocal disk and PBS was added, gently but well shaken, and the buffer removed from the confocal disk. The cells were fixed using ethanol $(70 \%, 200 \mu \mathrm{L})$ and the solution retained for $10 \mathrm{~min}$ for complete fixation. The incubated cells were again washed using PBS, shaken gently, and the medium completely removed from the confocal disk. For the staining, the cells were mounted with propidium iodide (PI) with buffer solution and again incubated at $37{ }^{\circ} \mathrm{C}$ for $30 \mathrm{~min}$ in an incubator and again washed with buffer. The stained cells were covered with a cover slip.

\section{mRNA extraction from $\mathrm{C} 2 \mathrm{C} 12$ cells}

Total RNA was extracted from the $\mathrm{C} 2 \mathrm{C} 12$ cells after various treatments for set periods of time using Trizol (Sigma) according to the manufacturer's protocol. The purity of the total RNA was assessed by the ratio of optical density at $260 \mathrm{~nm}$ to that at $280 \mathrm{~nm}$ (acceptable values being between 1.6 and 2.1). First, strand cDNA was synthesized from $1 \mu \mathrm{g}$ of the total RNA using M-MLV Reverse Transcriptase with Anchored Oligo d(T)12-18 Primer. Real-time PCR was performed using a cDNA equivalent of $10 \mathrm{ng}$ of total RNA from each sample with primers specific for caspase $3 / 7$ genes with a housekeeping gene GAPDH. The reaction was carried out in $10 \mu \mathrm{L}$ samples using SsoFastTM EvaGreen ${ }^{\circledR}$ Supermix (Bio-Rad) according to the manufacturers' instructions. Relative ratios were calculated based on the $2^{-\Delta \Delta C T}$ method. PCR was monitored using the CFX96TM Real-Time PCR Detection Systems (Bio-Rad).

\section{Analytical determination}

A concentration of $\alpha \mathrm{Fe}_{2} \mathrm{O}_{3} \mathrm{NPs}$ of $1 \mu \mathrm{g} \mathrm{mL}^{-1}$ was employed against suspended solutions of cancer cells (C2C12), and the quantity determined by the analytical method. The recorded absorption spectra of $\alpha \mathrm{Fe}_{2} \mathrm{O}_{3} \mathrm{NPs}, \mathrm{C} 2 \mathrm{C} 12$ and $\alpha \mathrm{Fe}_{2} \mathrm{O}_{3} \mathrm{NPs}$ were measured at $\lambda_{\max } 230$ and 440,290, $350 \mathrm{~nm}$, determined by a UV-visible spectrophotometer.

\section{Statistical analysis}

The obtained data is expressed as mean \pm SD. Statistical analysis was performed by Student $T$-tests. Results were considered significant when $P<0.05$.

\section{Result and discussion}

\section{X-ray diffraction pattern of $\alpha \mathrm{Fe}_{2} \mathrm{O}_{3}$ NPs}

The XRD spectrum shows a picture of the material crystallinity, phase and size of the prepared nanopowder. From a detailed observation of the obtained spectrum, it is evident from Fig. 1 that the prepared material is the hematite phase $\left(\alpha \mathrm{Fe}_{2} \mathrm{O}_{3}\right)$ of iron oxide NPs with the exact phases being compared with the available phase identification JCPDS card no. 39-1346. The peak positions, such as $23.70\langle 012\rangle, 32.70\langle 104\rangle, 35.10\langle 110\rangle, 40.40\langle 113\rangle, 43.35$ $\langle 202\rangle, 49.05\langle 024\rangle, 53.60\langle 116\rangle, 57.1\langle 018\rangle, 62.0\langle 214\rangle, 63.70\langle 300\rangle$, $69.02\langle 208\rangle, 71.65\langle 1010\rangle$ and $75.10\langle 220\rangle$, are clearly indexed with the phase of hematite $\left(\alpha \mathrm{Fe}_{2} \mathrm{O}_{3}\right)$ iron oxide. The average particle size of the prepared NPs is $\sim 12 \pm 3 \mathrm{~nm}$, as calculated by the Scherrer formula. ${ }^{38}$ From the spectrum, it is evident that no hydroxide

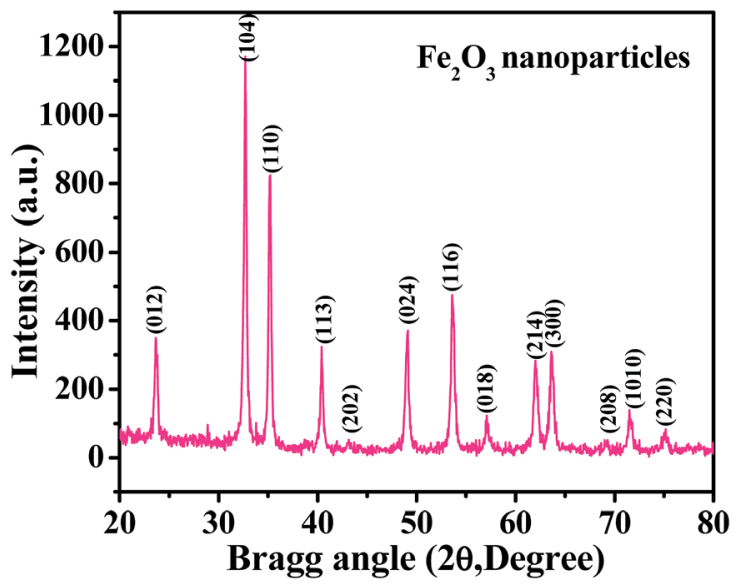

Fig. 1 The $\mathrm{X}$-ray diffraction pattern of iron oxide nanoparticles $\left(\alpha \mathrm{Fe}_{2} \mathrm{O}_{3}\right.$ hematite phase). 
peaks were observed, which again indicates that the transformation of hydroxide to hematite phase was complete.

\section{Structural, morphological and topographical descriptions of the prepared $\alpha \mathrm{Fe}_{2} \mathrm{O}_{3}$ NPs (FE-SEM and TEM results)}

The morphology of the prepared nanopowder was observed with FE-SEM and TEM. Fig. 2(a) and (b) show the low and high magnification images of the prepared $\alpha \mathrm{Fe}_{2} \mathrm{O}_{3} \mathrm{NPs}$. Several tiny NPs can be seen in the images in an agglomerated form (Fig. 2(b)). The high magnification image shows that the average size of each crystallite is about 12-15 $\mathrm{nm}$. To gain more detailed information about the morphology of the prepared NPs, TEM observation was performed at room temperature with an accelerating voltage of $200 \mathrm{kV}$. The low magnification image (Fig. 2(c)) shows the morphology of the prepared $\alpha \mathrm{Fe}_{2} \mathrm{O}_{3} \mathrm{NPs}$. The image shows that the NPs are very small and fine with an agglomerated form. Several tiny particles are in a clustered form; the clusters are made from very small hematite nanoparticles, which are about $\sim 12-15 \mathrm{~nm}$ in size in spherical dotlike structures. The obtained morphological observations of the NPs are in good agreement with the FESEM and XRD data. The size of each particle is about $12-15 \mathrm{~nm}$ with a spherical shape. Fig. 2(d) shows the high magnification TEM image of the prepared NPs, which illustrates that the lattice distance between two fringes is $\sim 0.233 \mathrm{~nm}$, which corresponds to the pure phase of $\alpha \mathrm{Fe}_{2} \mathrm{O}_{3}$ hematite NPs. We have also analyzed the dynamic light scattering (DLS) of the prepared NPs and this shows the size of the particulate matter to be about $110.2 \mathrm{~nm}$ (data not shown). We assume that several factors were influential, such as refluxing, precipitation time, concentration of salt etc. The size of the NPs increases with interaction with other molecules. Our findings also corroborate the findings of previous literature. ${ }^{39}$

\section{Atomic force microscopy (AFM results)}

The surface topography of the prepared $\alpha \mathrm{Fe}_{2} \mathrm{O}_{3} \mathrm{NPs}$ was observed from the AFM, which defines the size and surface
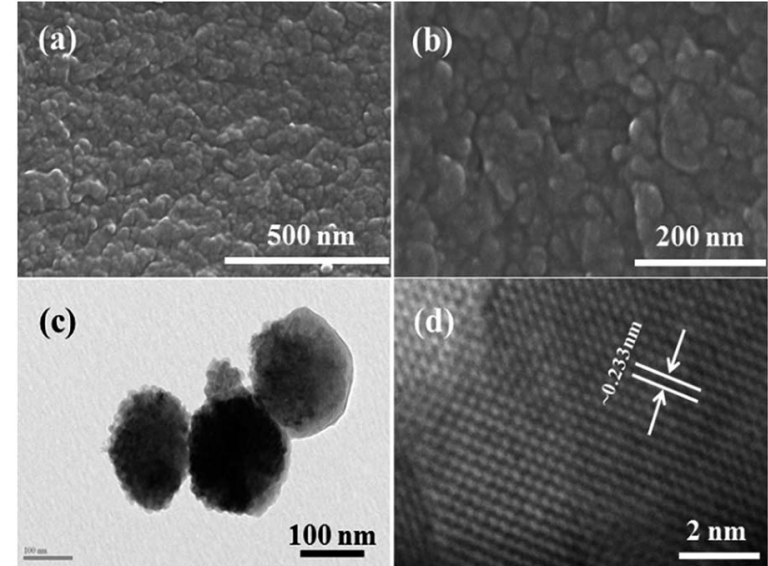

Fig. 2 Low (a) and high (b) magnification FE-SEM images of $\alpha \mathrm{Fe}_{2} \mathrm{O}_{3}$ hematite iron oxide nanoparticles, respectively. TEM (c) and HR-TEM (d) show the general morphology of the prepared NPs and their fringe distances between two lattices ( 0.233 nm). image of the prepared NPs. The obtained image shows that the particles are very small in diameter $(\sim 12-15 \mathrm{~nm})$, which provides clear and consistent data analogous to the $\mathrm{XRD}, \mathrm{FE}-$ SEM and TEM results. The AFM image of $\alpha \mathrm{Fe}_{2} \mathrm{O}_{3} \mathrm{NPs}$ (Fig. 3(a)) shows that several spherical shaped nanostructures can be seen on the surface of the silicon sheet which are in the size range of $\sim 12 \mathrm{~nm}$.

From the analysis in this section, it can easily be confirmed that the particles are $\sim 12 \mathrm{~nm}$ in size (Fig. 3(b)), which is in good agreement with the TEM observation (Fig. 2(c)). The surface and horizontal distance also confirm that the average size of each $\mathrm{NP}$ is in the range of about $\sim 12 \mathrm{~nm}$.

\section{FTIR spectroscopy results}

Information about the chemical functional bonding was obtained by Fourier transform infrared spectroscopic (FTIR) measurements using $\mathrm{KBr}$ (potassium bromide) pellets in the range of $4000-400 \mathrm{~cm}^{-1}$. In our experiment, a very small amount of hematite NPs powder was mixed with $\mathrm{KBr}$, which must be strictly controlled to produce good spectra. Consequently, the obtained mixture was compressed in the form of a pellet under high-pressure ( $\sim 4$ tons). The pellet was used for the FT-IR measurement. The FTIR spectrum shows the fingerprints of iron nitrate $\left(\mathrm{Fe}\left(\mathrm{NO}_{3}\right)_{3} \cdot 9 \mathrm{H}_{2} \mathrm{O}\right)$, sodium hydroxide $(\mathrm{NaOH})$ and $n$-propylamine, which were used for the formation of the hematite NPs. In the obtained spectrum (Fig. 4), we found that the broad peak between 3450 and $3250 \mathrm{~cm}^{-1}$ corresponding to the primary aliphatic amine ( $n$-propyl amine) shows broad band intensity in a liquid medium, whereas the asymmetric stretching of alcohol moisture molecules was centred at $1611 \mathrm{~cm}^{-1}$. The shifted stretching frequency of the primary amine at $998 \mathrm{~cm}^{-1}\left(-\mathrm{NH}_{2}\right)$ contributed hydrogen strength, and

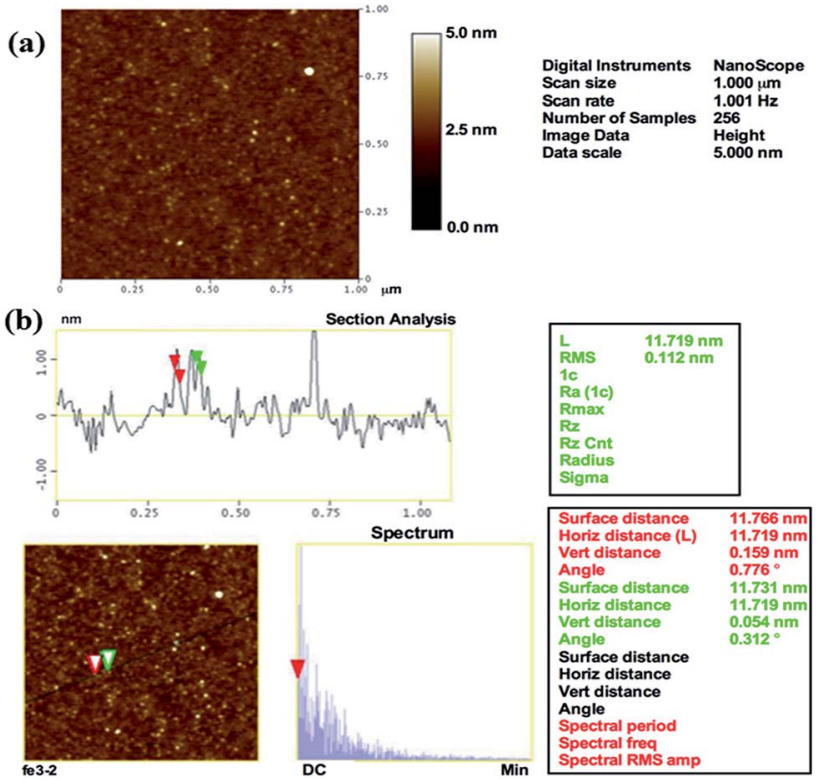

Fig. 3 AFM images of prepared $\alpha \mathrm{Fe}_{2} \mathrm{O}_{3}$ hematite iron oxide nanoparticles. General topographical image (a) whereas (b) shows the distance between particles, which is $\sim 12 \mathrm{~nm}$, (horizontal, vertical and surface distance). 


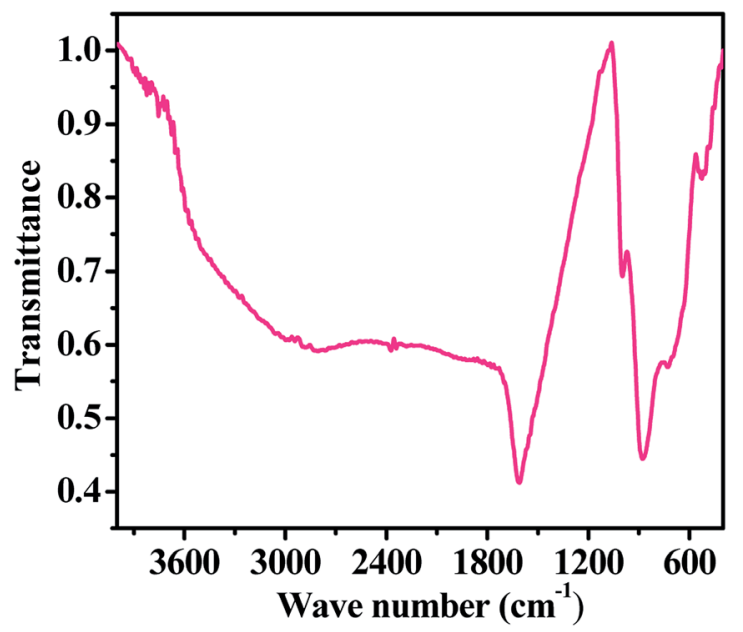

Fig. 4 The FTIR spectra of the prepared iron oxide nanoparticles $\left(\alpha \mathrm{Fe}_{2} \mathrm{O}_{3}\right.$ hematite phase).

alters in shape and position due to presence of hydrogen bonding in an alcoholic medium. A sharp peak centred at $876 \mathrm{~cm}^{-1}$ is associated with the stretching mode of the nitrate $\left(\mathrm{NO}_{3}{ }^{-1}\right)$ group from iron nitrate. ${ }^{25-28} \mathrm{~A}$ curved and flattened peak around $541 \mathrm{~cm}^{-1}$ in the FTIR spectrum represents the formation of $\mathrm{Fe}-\mathrm{O}$ and shows the metal oxide peak. The obtained functional information from FTIR justifies that the prepared nanostructures have a good chemical property and this is consistent with the XRD pattern data. We have not found any other residues because they were washed out during the washing of the prepared product with alcohol and acetone.

\section{Anticipated chemical reaction mechanism for $\alpha \mathrm{Fe}_{2} \mathrm{O}_{3} \mathrm{NPs}$}

On the basis of the chemical reaction used and observations such as the XRD, FE-SEM, TEM, AFM and FTIR findings, a chemical reaction mechanism is proposed for the formation of $\alpha \mathrm{Fe}_{2} \mathrm{O}_{3}$ NPs. In this experiment, when the iron(III) nitrate nonahydrate $\left(\mathrm{Fe}\left(\mathrm{NO}_{3}\right)_{3} \cdot 9 \mathrm{H}_{2} \mathrm{O}\right)$ was dissolved in $\mathrm{MeOH}$ under continuous stirring and $n$-propylamine and $\mathrm{NaOH}$ were added to this suspension, it forms a clear solution without a precipitate at a $\mathrm{pH}$ of 12.06. At the desired refluxing temperature of $\sim 90{ }^{\circ} \mathrm{C}$, a precipitate started to form in the refluxing pot. And it was completed in $60 \mathrm{~min}$. As for the chemical reactions, it is assumed that the nitrate $\left(-\mathrm{NO}_{3}\right)_{2}$ group from iron(III) nitrate nonahydrate $\left(\mathrm{Fe}\left(\mathrm{NO}_{3}\right)_{3} \cdot 9 \mathrm{H}_{2} \mathrm{O}\right)$ reacted with sodium $\left(\mathrm{Na}^{+}\right)$ions due to the strong electro-negativity factor. The amine $\left(-\mathrm{NH}_{2}\right)$ chain from $n$-propylamine reacted with the iron $\left(\mathrm{Fe}^{3+}\right)$ ions and formed a long chain with the amine complex $\left(\mathrm{FeN}-\left(\mathrm{CH}_{2}\right)_{2}-\right.$ $\mathrm{CH}_{3}$ ), which may be due to the decomposition of the hydrogen bond in the solution. As the reaction temperature rises, the hydroxyl $\left(\mathrm{OH}^{-}\right)$ions from sodium react with the iron complex $\left(\mathrm{FeN}-\left(\mathrm{CH}_{2}\right)_{2}-\mathrm{CH}_{3}\right)$, and the $\left(\mathrm{Fe}^{3+}\right)$ ions react with the hydroxyl (ions), forming iron hydroxide $\left(\mathrm{Fe}(\mathrm{OH})_{3}\right)$. This hydroxide $\left(\mathrm{Fe}(\mathrm{OH})_{3}\right)$ molecule was further changed into iron oxide $\left(\mathrm{Fe}_{2} \mathrm{O}_{3}\right)$ due to refluxing and drying with $\mathrm{MeOH}$ from the compound. The mechanism was also justified with the available FTIR data (Fig. 4). As found in previous literature, at a higher refluxing temperature hydroxide molecules change into pure oxide material upon heating and drying. The product/residue formed from the reaction was leached out during washing, and centrifugation of the product. ${ }^{40,41}$

\section{Morphological evaluation (C2C12) and their interaction effect with $\alpha \mathrm{Fe}_{2} \mathrm{O}_{3} \mathrm{NPs}$}

The C2C12 cells were cultured in a specified $75 \mathrm{~mm}^{2}$ flask and grown at their confluence $(50-70 \%)$. When the cells reached their optimum confluence (50-70\%), they were again harvested with trypsin and treated with the prepared $\alpha \mathrm{Fe}_{2} \mathrm{O}_{3} \mathrm{NPs}$ at

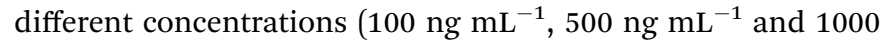
$\mathrm{ng} \mathrm{mL}^{-1}$ ). A control was also managed to check the difference between treated and untreated samples. The samples were incubated with $5 \% \mathrm{CO}_{2}$ at $37{ }^{\circ} \mathrm{C}$ for different time $(24,48$, and $72 \mathrm{~h}$ ) periods (Fig. 5). Initially, no changes were observed in the culture medium but after $24 \mathrm{~h}$, cells were seen to be mono nucleate and started to proliferate $(48 \mathrm{~h})$ and as the incubation time reached $72 \mathrm{~h}$, the cells were damaged (Fig. 5). It is very clear from the images that as the concentration $\left(100 \mathrm{ng} \mathrm{mL}^{-1}, 500 \mathrm{ng}\right.$ $\mathrm{mL}^{-1}$ and $1000 \mathrm{ng} \mathrm{mL} \mathrm{m}^{-1}$ ) of NPs increases, the cells' viability was damaged by interaction with the prepared nanomaterial. ${ }^{42,43}$

\section{MTT assay or cytotoxicity calculations}

The obtained MTT results showed that the \% viable cells varied in a dose/concentration-dependent manner. The cell viabilities at concentrations of $100 \mathrm{ng} \mathrm{mL} L^{-1}, 500 \mathrm{ng} \mathrm{mL} \mathrm{m}^{-1}$ and $1000 \mathrm{ng}$ $\mathrm{mL}^{-1}$ were recorded as $87 \%, 55 \%$ and $48 \%$, respectively, by MTT assay at $24 \mathrm{~h}$. With an increase in incubation, a sequential change in cell viability was observed at $100 \mathrm{ng} \mathrm{mL}^{-1}, 500 \mathrm{ng}$ $\mathrm{mL}^{-1}$ and $1000 \mathrm{ng} \mathrm{mL}^{-1}$ concentrations and was recorded as $60 \%, 50 \%$ and $3 \%$, respectively, by MTT assay at $48 \mathrm{~h}$. With a $72 \mathrm{~h}$ incubation period, a sudden drop in viability was observed for $100 \mathrm{ng} \mathrm{mL}^{-1}, 500 \mathrm{ng} \mathrm{mL}^{-1}$ and $1000 \mathrm{ng} \mathrm{mL}^{-1}$ concentrations to $57 \%, 41 \%$ and $31 \%$, respectively, by MTT assay (Fig. 6). Similar results were also found with C2C12 cells with various concentrations using platinum quantum dots, gold nanoparticles and also metal oxide/zinc oxide

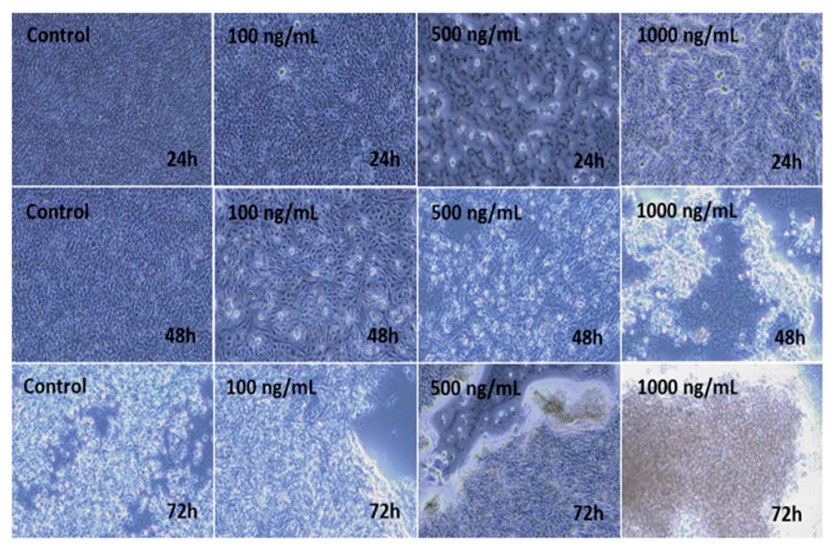

Fig. 5 Microscopic images of the effect on $\mathrm{C} 2 \mathrm{C} 12$ of iron oxide $\alpha \mathrm{Fe}_{2} \mathrm{O}_{3}$ (hematite phase) nanoparticles at different concentrations and incubation times. 
nanoparticles. ${ }^{40,42,43}$ The obtained result signifies that the prepared hematite NPs reduce the viability of cancer cells at different nanogram (100 ng mL $\mathrm{mL}^{-1}, 500 \mathrm{ng} \mathrm{mL} \mathrm{m}^{-1}$ and $1000 \mathrm{ng}$ $\left.\mathrm{mL}^{-1}\right)$ concentration levels for different incubation $(24,48$ and $72 \mathrm{~h}$ ) periods.

\section{Caspase- 3 and 7 activity effect with $\alpha \mathrm{Fe}_{2} \mathrm{O}_{3}$ NPs}

The levels of mRNA in the presence of caspase 3 and 7 genes against C2C12 cells with the incorporation of $\alpha \mathrm{Fe}_{2} \mathrm{O}_{3} \mathrm{NPs}$ (in the presence of GAPDH) were analyzed with RT-PCR. The cells were treated with NPs at defined (500 $\left.\mathrm{ng} \mathrm{mL}^{-1} \& 1000 \mathrm{ng} \mathrm{mL}^{-1}\right)$ concentrations for two different incubation $(24 \& 72 \mathrm{~h})$ periods. After analysis, the obtained data from PCR show that the levels of mRNA for the markers (caspase 3 and 7) were considerably changed in the cancer cells, which is due to exposure to $\alpha \mathrm{Fe}_{2}-$ $\mathrm{O}_{3}$ NPs (Fig. 7 and $8, p<0.05$ for each). According to the obtained data, the genes' expressions for caspase 3 with $\alpha \mathrm{Fe}_{2} \mathrm{O}_{3}$ NPs at $100 \mathrm{ng} \mathrm{mL}^{-1}$ at $24 \mathrm{~h}$ incubation period were 1.32 and 2.51 , respectively. The amounts of change at a high $\left(1000 \mathrm{ng} \mathrm{mL}^{-1}\right)$ concentration of $\alpha \mathrm{Fe}_{2} \mathrm{O}_{3} \mathrm{NPs}$ with $72 \mathrm{~h}$ incubation period were 2.02 and 4.30 fold, respectively, defining a gradual change, due to the upregulation of the genes (Fig. 7). The quantitative realtime PCR results indicated that $\alpha \mathrm{Fe}_{2} \mathrm{O}_{3} \mathrm{NPs}$ show upregulation in the mRNA level of the cell cycle checkpoint of caspase 3 and $7 .^{44}$ The caspase activities correspond to the portion of apoptotic cells present in the naturally growing population due to natural aging in untreated cells.

The role of alteration in gene expression was associated with an untreated sample as a control or a signature control (GAPDH) for the knockdown data. Generally the prepared metal oxide nanostructures (NPs) behave with a toxic nature with respect to the growth of cancer cells, as is very clear from the obtained data (Fig. 7 and 8).

As the concentration of NPs increases, the cell apoptosis increases and this resulted in upregulation in mRNA expression. Similar observations were also obtained in the case of caspase 7 , when it was introduced after 24 and $72 \mathrm{~h}$ incubations in the presence of NPs. In the case of caspase 7 gene expression, at low concentration $\left(100 \mathrm{ng} \mathrm{mL}^{-1}\right)$ of NPs incubated for $24 \mathrm{~h}$, it

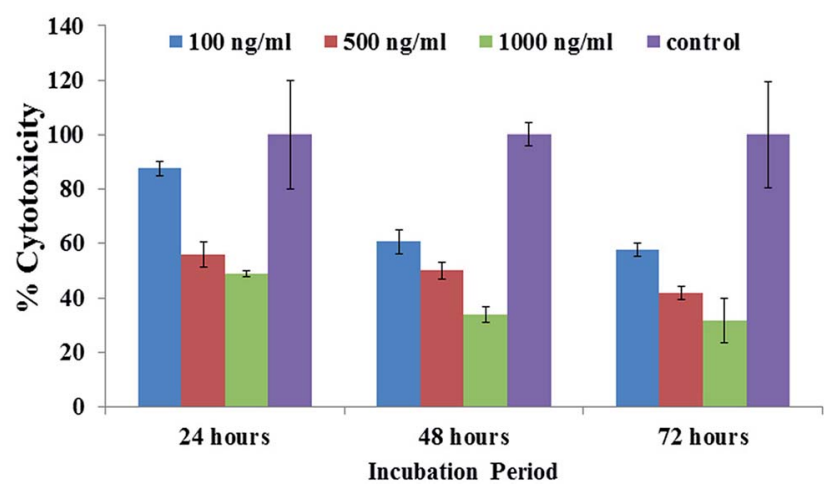

Fig. 6 The MTT assay of iron oxide nanoparticles $\left(\alpha \mathrm{Fe}_{2} \mathrm{O}_{3}\right.$ hematite phase) at different concentrations (100 ng mL $-1,500 \mathrm{ng} \mathrm{mL}^{-1}$ and $1000 \mathrm{ng} \mathrm{mL}^{-1}$ ) and incubation (24,48 and $72 \mathrm{~h}$ ) times and with a control solution. Experiments were performed in a triplicate manner.

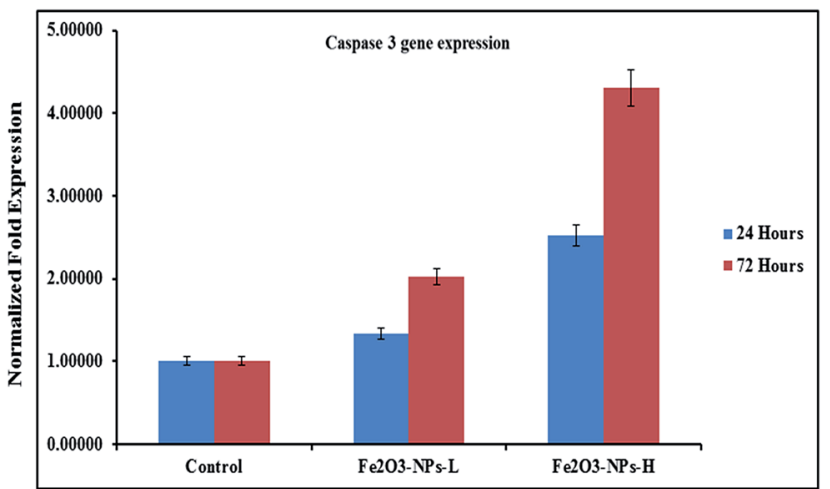

Fig. 7 mRNA expression of $\mathrm{C} 2 \mathrm{C} 12$ cells for caspase 3 in the presence of GAPDH genes, with exposure to NPs at low (500 $\mathrm{ng} \mathrm{mL}^{-1}$ ) and high (1000 ng mL $\mathrm{m}^{-1}$ ) concentrations. Experiments were performed in a triplicate manner.

expressed 2.30 and 4.27 fold change respectively, whereas at a higher concentration $\left(1000 \mathrm{ng} \mathrm{mL}^{-1}\right.$ ) of $\alpha \mathrm{Fe}_{2} \mathrm{O}_{3} \mathrm{NPs}$ and higher incubation period $(72 \mathrm{~h})$, apoptosis changes were 2.26 to 5.83 fold (Fig. 8). ${ }^{44}$

\section{Confocal laser scanning microscopy (CLSM) study effect with $\alpha \mathrm{Fe}_{2} \mathrm{O}_{3} \mathrm{NPs}$}

The dead and live cells and their morphology in a wet environment were also studied via CLSM in a dose-dependent manner with $5 \% \mathrm{CO}_{2}$ for a $24 \mathrm{~h}$ incubation period with the staining solution propidium iodide (PI). Fig. 9 shows the effect of different concentrations of $\alpha \mathrm{Fe}_{2} \mathrm{O}_{3} \mathrm{NPs}$ from low (100 ng $\mathrm{mL}^{-1}$ conc) to high (500 $\mathrm{ng} \mathrm{mL}^{-1} \& 1000 \mathrm{ng} \mathrm{mL}^{-1}$ ). From the images it is clear that at low concentration the toxicity of the nanostructures does not have much effect on the cells, but as the dose of NPs increases ( $500 \mathrm{ng} \mathrm{mL}^{-1} \& 1000 \mathrm{ng} \mathrm{mL}^{-1}$ ), more than $\sim 85-90 \%$ of the cells were completely damaged. Our results also corroborated the obtained MTT data (Fig. 6), and define that the toxicity to the cells is dependent on the concentration of utilized NPs and the ageing (incubation period) of the cells. This phenomenon is under investigation and the relation between NPs and cells lines needs to be confirmed. ${ }^{40,42,43}$

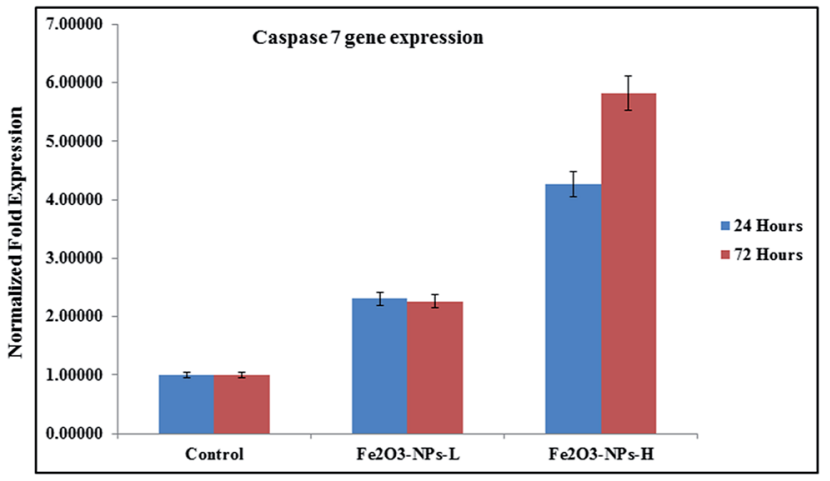

Fig. 8 mRNA expression of $\mathrm{C} 2 \mathrm{C} 12$ cells for caspase 7 in the presence of GAPDH genes, with exposure to NPs at low $\left(500 \mathrm{ng} \mathrm{mL}^{-1}\right)$ and high (1000 $\mathrm{ng} \mathrm{mL}^{-1}$ ) concentrations. 


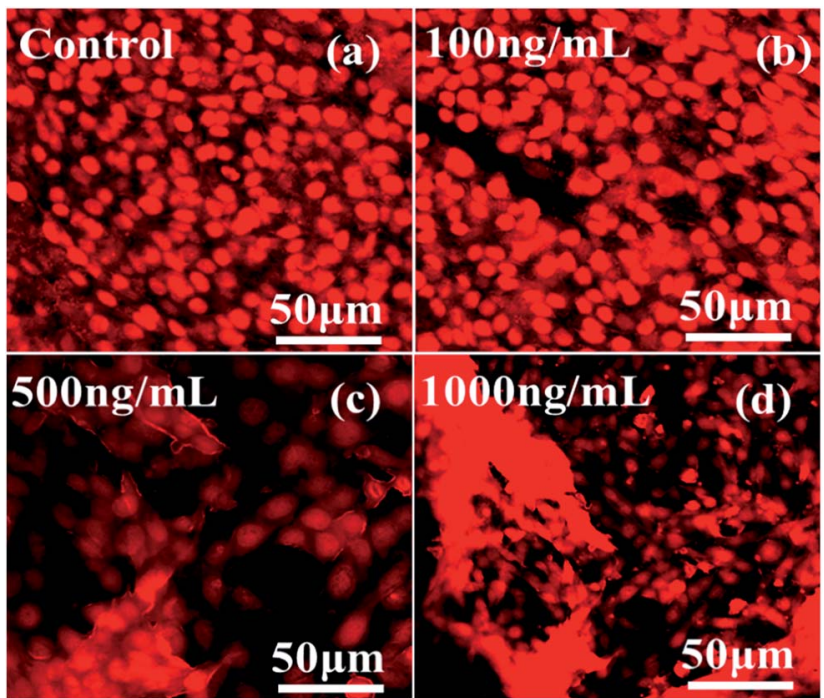

Fig. 9 CLSM images of $\mathrm{C} 2 \mathrm{C} 12$ cells at different concentrations of $\alpha \mathrm{Fe}_{2} \mathrm{O}_{3}$ hematite NPs (100 $\mathrm{ng} \mathrm{mL}^{-1}, 500 \mathrm{ng} \mathrm{mL}^{-1}$ and $1000 \mathrm{ng} \mathrm{mL}^{-1}$ ) with a $24 \mathrm{~h}$ incubation period.

\section{Analytical determinations of $\alpha \mathrm{Fe}_{2} \mathrm{O}_{3}$ NPs with C2C12 cells}

The analytical technique, regulatory markers, utilized a quantity of $\alpha \mathrm{Fe}_{2} \mathrm{O}_{3}$ NPs. This study will be helpful to differentiate the NPs before and after mingling with the $\mathrm{C} 2 \mathrm{C} 12$ cells $\left(\alpha \mathrm{Fe}_{2} \mathrm{O}_{3} \mathrm{NPs}\right.$ $\mathrm{C} 2 \mathrm{C} 12)$ component. In the present case the quantity of utilized sample and their molecular species absorb radiation with respect to a suitable wavelength $(\mathrm{nm})$ at maximum absorption $\left(\lambda_{\max }\right)$. The quality of the analytes (the essential ability of the nanomaterials $\left(\alpha \mathrm{Fe}_{2} \mathrm{O}_{3} \mathrm{NPs}\right)$ to control caspase 3 and 7 genes in $\mathrm{C} 2 \mathrm{C} 12$ cells) was analyzed via optimization and validation methods. The statistical analytical technique has the ability to provide information about the relation between both chemical and biological quantized species which distinguishes the resulting data. In our results, which are illustrated as Fig. 10(a-c), the absorbance of $\alpha \mathrm{Fe}_{2} \mathrm{O}_{3}$ NPs was displayed at two positions at $\lambda_{\max } 220$ and $430 \mathrm{~nm}$, whereas the $\mathrm{C} 2 \mathrm{C} 12$ and $\alpha \mathrm{Fe}_{2} \mathrm{O}_{3}$ NPs-C2C12 show absorbance at $\lambda_{\max } 290$ and $360 \mathrm{~nm}$ wavelength, respectively. On the basis of the obtained data a calibration graph was constructed for the $\alpha \mathrm{Fe}_{2}-$ $\mathrm{O}_{3} \mathrm{NPs}$ by plotting absorbance against concentration (conc., 0.5$2.0 \mu \mathrm{g} \mathrm{mL} \mathrm{m}^{-1}$ ) which gives a linear graph (Fig. 11). The linear regressive equation $(A=0.109+1.732 C)$ of the calibration data obtained $(n=5)$ with the help of absorbance versus concentration, gives the value of the intercept (a), slope (b), and correlation coefficient. ${ }^{45,46}$ The high molar absorptivity $\left(\alpha \mathrm{Fe}_{2} \mathrm{O}_{3} \mathrm{NPs}=9.20 \times\right.$ $10^{3} \mathrm{~L} \mathrm{~mol}^{-1} \mathrm{~cm}^{-1}$ ) of the resulting sample solution indicates the sensitivity, detection limit (LOD) and quantitation limit (LOQ), relative standard deviation (RSD), showing the system suitability of the proposed method at the lowest concentration level. ${ }^{47,48}$ These empirical formulae provided more reliable values to ensure that they are fit for the proposed method and confirmed that this method is accurate, precise, reproducible, and gives adequate results. The recovery and relative standard deviation (RSD) experiments are summarized in Tables S1 and S2. $\dagger$ It is evident from both tables that the recoveries (99.54-100.94\%) were almost accurate and were satisfactory. ${ }^{47,48}$

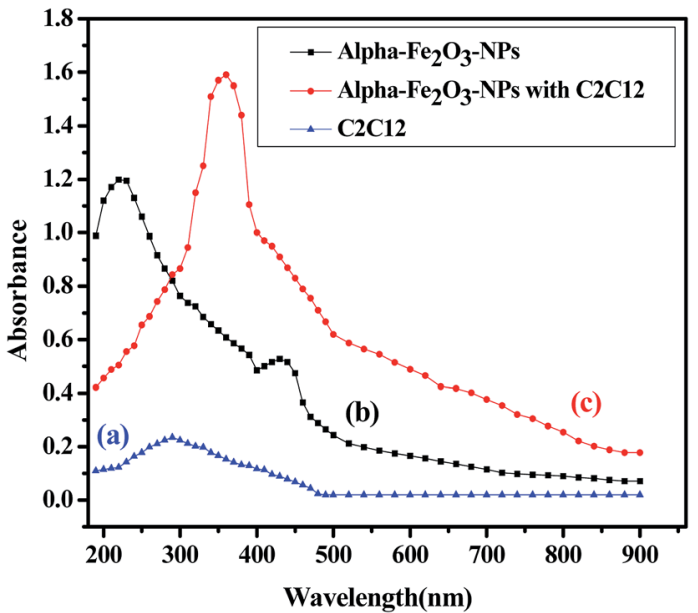

Fig. 10 The absorption spectra of $\alpha \mathrm{Fe}_{2} \mathrm{O}_{3} \mathrm{NPs}$ (a), $\mathrm{C} 2 \mathrm{C} 12$ cells (b), spectra of $\alpha \mathrm{Fe}_{2} \mathrm{O}_{3} \mathrm{NPs}$ and $\mathrm{C} 2 \mathrm{C} 12$ cells (c).

\section{Possible proposed mechanism}

On the basis of obtained data the exact mechanism of cytotoxicity with $\alpha \mathrm{Fe}_{2} \mathrm{O}_{3}$ NPs and damage to cells and their organelles is still under debate, but from our observations, such as morphology, cell viability, PCR detection with caspase 3 and 7 genes and CLSM study, we have projected and explained the cause of cell damage with $\alpha \mathrm{Fe}_{2} \mathrm{O}_{3} \mathrm{NPs}$ in a possible pictorial mechanism (Fig. 12), relating to cytotoxicity happening with $\alpha \mathrm{Fe}_{2} \mathrm{O}_{3} \mathrm{NPs}$. The toxicity to the cells depends on various types of parameters, such as the size of the nanostructures used, the shape of the material, chemical content, and dose/ concentration of NPs, cell concentration etc. It also affects the endocytic uptake of cells..$^{40,42,43,49}$ In our case it is assumed that the $\alpha \mathrm{Fe}_{2} \mathrm{O}_{3}$ NPs are very small $(12-15 \mathrm{~nm})$ and spherical in shape so they can easily enter into the cell membrane because the size of each cell is usually around $\sim 20 \mu \mathrm{m}$, which means enough space for the nanostructures to enter into the cells. The $\alpha \mathrm{Fe}_{2} \mathrm{O}_{3} \mathrm{NPs}$ first attack the surface of the cancerous cells and then the cell membranes which exhibit small pores/passages in their organization, facilitates entry of small $\alpha \mathrm{Fe}_{2} \mathrm{O}_{3}$ NPs into cells and damages the upper layer of the cell walls (as in the schematic in Fig. 12). As with our obtained result at $100 \mathrm{ng}$

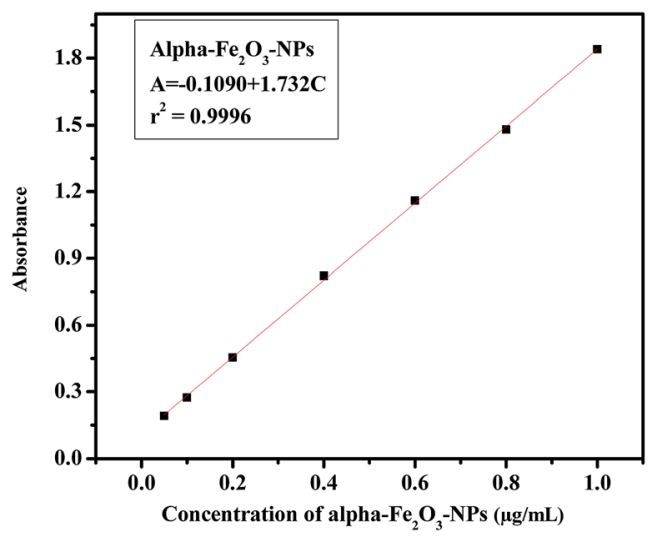

Fig. 11 The linear calibration graph of $\alpha \mathrm{Fe}_{2} \mathrm{O}_{3} \mathrm{NPs}$. 


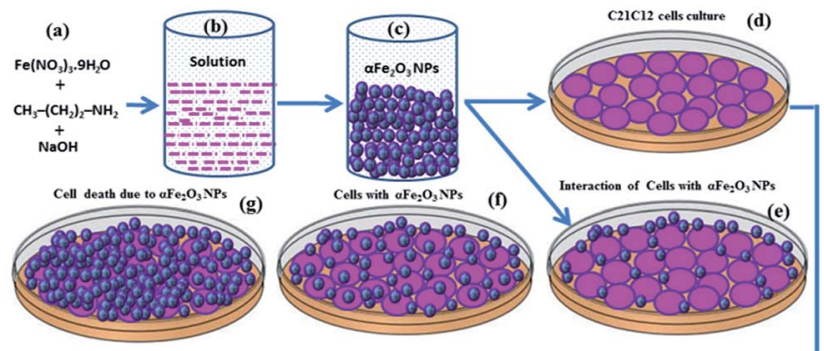

Analytical determination of cultured cells with $\alpha \mathrm{Fe}_{2} \mathrm{O}_{3} \mathrm{NPs}$

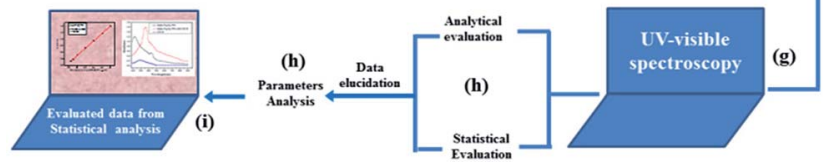

Fig. 12 Possible proposed schematic mechanism for the interaction of $\alpha \mathrm{Fe}_{2} \mathrm{O}_{3} \mathrm{NP}$ against $\mathrm{C} 2 \mathrm{C} 12$ and their cytological death.

$\mathrm{mL}^{-1}$ concentration of NPs, the density of damaged cells is lower because of the concentration as compared to higher applied doses such as 500 or $1000 \mathrm{ng} \mathrm{mL} \mathrm{m}^{-1}$ concentration of $\alpha \mathrm{Fe}_{2} \mathrm{O}_{3} \mathrm{NPs}$. The very small size of the nanoparticles relative to the cell size as well as the high density of $\alpha \mathrm{Fe}_{2} \mathrm{O}_{3} \mathrm{NPs}$ in liquids can strongly favor the rapid formation of adduct. ${ }^{40,42,43,49}$ It is assumed that adducts formed of $\alpha \mathrm{Fe}_{2} \mathrm{O}_{3} \mathrm{NPs}$ have the ability to destroy the cell organelles, which ultimately succumb to cell death.

In case of analytical performance, the statistical interpretations and their validation were studied under International Conference of Harmonization (ICH) guidelines. This (ICH) guideline recommends validation characteristics of analytical methods such as: linearity, range, accuracy, precision, repeatability, specificity, LOD and LOQ. ${ }^{45,46}$ The statistical analytical parameters playing an important role in promoting and encouraging the capability of a nanomaterial include the mean, standard deviation, variance and standard analytical error, RSD, coefficient of correlation, regression line, variance, errors in the slope and the intercept, and confidence limit for the slope and the intercept. For the statistical analysis performance an appropriate quantity of $\alpha \mathrm{Fe}_{2} \mathrm{O}_{3} \mathrm{NPs}$ solution was dedicated to control toxicity in cancerous cells. Therefore, prerequisites, assumptions and formulae were employed at a low concentration level to design an experimental plan for strictly defined standard quantitative and qualitative results to specify reaction conditions. The UV-visible spectrophotometer technique provides absorption spectra in regard to absorbance, and more reliable values of the resulting data confirm the relationship and interaction between $\alpha \mathrm{Fe}_{2} \mathrm{O}_{3} \mathrm{NPs}$ and $\mathrm{C} 2 \mathrm{C} 12$ cancerous cells. The aptitude of the analytical procedure to achieve test results is directly proportional to the concentration of $\alpha \mathrm{Fe}_{2} \mathrm{O}_{3} \mathrm{NPs}$ in the sample solutions. Beer's law was followed in the concentration range from 0.05 to $1.0 \mu \mathrm{g} \mathrm{mL} \mathrm{m}^{-1}$ and, therefore, this solution range was fixed for $\alpha \mathrm{Fe}_{2} \mathrm{O}_{3}$ NPs (Fig. 10). The linearity represents the ability to use regression equation analysis $(A=-0.109+1.732 C)$ of the calibration data obtained $(n=5)$ with the help of $\alpha \mathrm{Fe}_{2} \mathrm{O}_{3} \mathrm{NPs}$ absorbance versus concentration, which gives the value of the intercept (a), slope (b), apparent molar absorptivity $\left(\alpha \mathrm{Fe}_{2} \mathrm{O}_{3} \mathrm{NPs}=\right.$ $\left.9.20 \times 10^{3} \mathrm{~L} \mathrm{~mol}^{-1} \mathrm{~cm}^{-1}\right)$, variance of the slope of the regression line $\left(\mathrm{So}^{2}=2.04 \times 10^{-4}\right)$, correlation coefficient $\left(r^{2}=0.9996\right),\left( \pm t_{\mathrm{Sa}}\right.$
$=0.013$ and $\left.\pm t_{\mathrm{Sb}}=0.024\right)$, limits of detection $(\mathrm{LOD}=402.5 \mu \mathrm{g}$ $\left.\mathrm{mL}^{-1}\right)$ and limit of quantitation ( $\left.\mathrm{LOQ}=1219.7 \mu \mathrm{g} \mathrm{mL}{ }^{-1}\right)$ at a $95 \%$ confidence level (Table $\mathrm{S} 1 \dagger$ ). Accuracy and precision were achieved with replicate sets of $\alpha \mathrm{Fe}_{2} \mathrm{O}_{3} \mathrm{NPs}$ (analyte) with respect to three concentrations, which represented the entire range of the standard linear curve (Fig. 11). To evaluate intra-day and inter-day precision, analyses of $\alpha \mathrm{Fe}_{2} \mathrm{O}_{3} \mathrm{NPs}$ at three concentration levels (0.221, 0.732 and $1.125 \mu \mathrm{g} \mathrm{mL} \mathrm{m}^{-1}$ ) were carried out within the same day and on five consecutive days. The intra-day and inter-day RSD values for $\alpha \mathrm{Fe}_{2} \mathrm{O}_{3} \mathrm{NPs}$ ranged from 0.918 to $1.951 \%$ and from 1.483 to $1.814 \%$, respectively, and the obtained results are summarized in Table S2. $\dagger$ The $\%$ recoveries were quantitative for $\alpha \mathrm{Fe}_{2} \mathrm{O}_{3} \mathrm{NPs}$ (99.31-100.94\%), indicating good accuracy of the proposed method and satisfactory recovery with values of RSD (\%) analyzed by a spectrophotometric method. All resulting data conform strictly to statistical analysis and acceptable accuracy and precision under the quantified level to sustain bioavailability with caspase 3 and 7 in $\mathrm{C} 2 \mathrm{C} 12$ cells. The reliable results are satisfactory and fully validated according to acceptance criteria from an assay performance of statistical analysis, giving an appropriate quantity of analytes to reduce or control the multiplication of $\mathrm{C} 2 \mathrm{C} 12$ cells. The toxicity to biological materials (cancerous cells) was good, supporting the selection of $\alpha \mathrm{Fe}_{2} \mathrm{O}_{3} \mathrm{NPs}$, and the species integrity maintained a quantity which allowed the endorsement of standardized nanomaterials for use as a proper essential ingredient at a low limit of quantified levels. Hence, the statistical analytical techniques recommended in the specification validated the resulting data and ensured it achieved a 95\% confidence level. ${ }^{45-48}$

\section{Conclusion}

In the present work, we have successfully synthesized spherical shaped $\alpha-\mathrm{Fe}_{2} \mathrm{O}_{3}$ hematite iron oxide NPs via a solution process at low cost. The particles were characterized with the available sophisticated instruments in terms of their crystalline character and morphology, such as X-ray diffraction pattern, FESEM and TEM, respectively. The chemical functional footprints were analysed via FTIR spectroscopy. The prepared NPs $(\sim 12-15 \mathrm{~nm})$ were utilized to control the proliferation of cancer cells C2C12 cells in a dose-dependent manner. The viability of the cells was examined with MTT assay which revealed that enhanced cell death was caused in a dose-dependent manner, which plays an important role in controlling the density of cells. Included in this study, the density of dead cells in a wet environment was also approved from the CLSM study. The cell apoptosis of $\mathrm{C} 2 \mathrm{C} 12$ in the presence of caspases 3 and 7 with GAPDH genes with controlled doses of $\alpha-\mathrm{Fe}_{2} \mathrm{O}_{3}$ hematite iron oxide NPs was checked with RT-PCR study. To validate the obtained study, an analytical technique was employed in terms of the determination of nanomaterials, selected for reduction in cell viability and controlling the growth of cancerous cells. The applicability of the NPs is the right choice for the purpose of cancerous cell inhibition. The statistical parameters validated the performance, where the suitability, selectivity, sensitivity, rapidity accuracy, and precision were the main advantages of the proposed method. The statistical analytical parameters such as the mean $(X)$, standard deviation $(\mathrm{SD})$, relative standard 
deviation (RSD) and confidence limit (C.L.) at 95\% were calculated in order to verify the validity of the experimental data, to check the anticancerous effects. The small NPs are highly effective against the proliferation rate of cancer cells and the analytical determination techniques define the quality of the results. The obtained statistical results show higher accuracy with reproducibility, as indicated by the qualitative and quantitative results from UV-visible spectroscopy. Under the $\mathrm{ICH}$ guidelines, the analytical parameters were authenticated and studied for the validation and standardization of analytical procedures for the approval and authentication of the result.

\section{Conflicts of interest}

The authors declare that there are no conflicts of interest.

\section{Acknowledgements}

This study was financially supported by the King Saud University, Vice Deanship of Research Chairs.

\section{References}

1 A. Akbarzadeh, M. Samiei and S. Davaran, Nanoscale Res. Lett., 2012, 7, 144.

2 M. Marcus, M. Karni, K. Baranes, I. Levy, N. Alon, S. Marge and O. Shefi, J. Nanobiotechnol., 2016, 14, 37.

3 M. Mahmoudi, F. Q. Pluck, M. P. Monopoli, S. Sheibani, H. Vali, K. A. Dawson and I. Lynch, ACS Chem. Neurosci., 2013, 4(3), 475-485.

4 K. K. Atyam, A. Ghosh, K. Mukherjee and S. B. Majumder, Hematite iron oxide nano-particles: facile synthesis and their chemi-resistive response towards hydrogen, Mater. Res. Express, 2015, 2, 055901.

5 K. Kim, I. H. Kim, K. Y. Yoon, J. Lee and J. H. Jang, $\alpha-\mathrm{Fe}_{2} \mathrm{O}_{3}$ on patterned fluorine doped tin oxide for efficient Photo electrochemical water splitting, J. Mater. Chem. A, 2015, 3, 7706-7709.

6 L. Cui, D. Zhao, Y. Yang, Y. Wang and X. Zhang, Synthesis of highly efficient $\alpha-\mathrm{Fe}_{2} \mathrm{O}_{3}$ catalysts for $\mathrm{CO}$ oxidation derived from MIL-100 (Fe), J. Solid State Chem., 2017, 247, 168-172.

7 H. Katsuki and S. Komarneni, J. Am. Ceram. Soc., 2003, 86(1), 183-185.

8 Y. Fu, J. Wang, H. Y. Yu, X. Li, H. Wang, J. H. Tian and R. Yang, Int. J. Hydrogen Energy, 2017, 42(32), 20711-20719.

9 G. Haiying, J. Tifeng, Z. Qingrui, L. Adan and G. Faming, Rare Met. Mater. Eng., 2015, 44(11), 2688-2691.

10 B. P. Singh, A. Kumar, A. P. Duarte, S. J. Rojas, M. C. Medina, H. I. A. Martinez, C. A. V. Olivencia and M. S. Tomar, Mater. Res. Express, 2015, 3, 106105.

11 A. Mirzaei, K. Janghorban, B. Hashemi, A. Bonavita, M. Bonyani, S. G. Leonardi and G. Neri, Nanomaterials, 2015, 5, 737-749.

12 H. Niu, S. Zhang, Q. Ma, S. Qin, L. Wan, J. Xu and S. Miao, RSC Adv. , 2013, 3, 17228-17235.

13 E. M. Verdugo, Y. Xie, J. Baltrusaitis and D. M. Cwiertny, $R S C$ Adv., 2016, 6, 99997-100007.
14 Z. Ma, X. Huang, S. Dou, J. Wu and S. Wang, J. Phys. Chem. C, 2014, 118(31), 17231-17239.

15 Y. M. Lin, P. R. Abel, A. Heller and C. B. Mullins, J. Phys. Chem. Lett., 2011, 2(22), 2885-2891.

16 N. Yan, X. Zhou, Y. Li, F. Wang, H. Zhong, H. Wang and Q. Chen, Sci. Rep., 2013, 3, 3392.

17 J. R. Griffiths and J. D. Glickson, Adv. Drug Delivery Rev., 2000, 41(1), 75-89.

18 M. M. B. Abbad, M. S. Takriff, A. Benamor and A. W. Mohammad, J. Sol-Gel Sci. Technol., 2017, 81(3), 880893.

19 L. Liu, H. Z. Kou, W. Mo, H. Liu and Y. Wang, J. Phys. Chem. $B, 2006,110(31), 15218-15223$.

20 M. Tadic, M. Panjan, V. Damnjanovic and I. Milosevic, Appl. Surf. Sci., 2014, 320, 183-187.

21 T. Tsuzuki, F. Schäffel, M. Muroi and P. G. McCormick, Powder Technol., 2011, 210(3), 198-202.

22 A. K. Mondal, S. Chen, D. Su, K. Kretschmer, H. Liu and G. Wang, J. Alloys Compd., 2015, 648, 732-739.

23 S. G. Hosseini and E. Ayoman, J. Therm. Anal. Calorim., 2017, 128(2), 915-924.

24 Z. Pu, M. Cao, J. Yang, K. Huang and C. Hu, Nanotechnology, 2006, $17(3)$, 799-804.

25 A. Lassoued, B. Dkhil, A. Gadri and S. Ammara, Results Phys., 2017, 7, 3007-3015.

26 F. S. Yen, W. C. Chen, J. M. Yang and C. T. Hong, Nano Lett., 2002, 2(3), 245-252.

27 J. A. Morales-Morales, Ciencia en Desarrollo, 2017, 8(1), 99107.

28 K. Shimizu, S. V. Sokolov and R. G. Compton, Colloid Interface Sci. Commun., 2016, 13, 19-22.

29 Q. A. Pankhurst, J. Connolly, S. K. Jones and J. Dobson, J. Phys. D: Appl. Phys., 2003, 36, R167-R181.

30 P. Polak and O. Shefi, Nanomedicine, 2015, 11, 1467-1479.

31 A. Ali, H. Zafar, M. Zia, I. Haq, A. R. Phull, J. S. Ali and A. Hussain, Nanotechnol., Sci. Appl., 2016, 9, 49-67.

32 K. Rajendran, V. Karunagaran, B. Mahanty and S. Sen, Int. J. Biol. Macromol., 2015, 74, 376-381.

33 C. A. Pacak, P. E. Hammer, A. A. MacKay, R. P. Dowd, K. R. Wang, A. Masuzawa, B. Sill, J. D. McCully and D. B. Cowan, PLoS One, 2014, 9(9), e108695.

34 M. Tadic, L. Kopanja, M. Panjan, S. Kralj, J. N. Runice and Z. Stojanovic, Appl. Surf. Sci., 2017, 403, 628-634.

35 D. Cardillo, M. Tehei, M. S. Hossain, M. M. Islam, K. Bogusz, D. Shi, D. Mitchell, M. Lerch, A. Rosenfeld, S. Corde and K. Konstantinov, ACS Appl. Mater. Interfaces, 2016, 8(9), 5867-5876.

36 S. Kanagesan, M. Hashim, S. Tamilselvan, N. B. Alitheen, I. Ismail, A. Hajalilou and K. Ahsanul, Adv. Mater. Sci. Eng., 2013, 201, 710432.

37 A. Yanai, U. O. Hfeli, A. L. Metcalfe, P. Soema, L. Addo, C. Y. G. Evans, K. Po, X. Shan, O. L. Moritz and K. G. Evans, Cell Transplant., 2012, 21, 1137-1148.

38 B. D. Cullity, Elements of X-Ray Diffraction, Addison-Wesley, Reading MA, 1978, p. 102. 
39 W. Cui, J. Li, Y. Zhang, H. Rong, W. Lu and L. Jiang, Nanomedicine: Nanotechnology, Biology and Medicine, 2012, 8(1), 46-53.

40 R. Wahab, F. Khan, Y. B. Yang, I. H. Hwang, H. S. Shin, J. Ahmad, S. Dwivedi, S. T. Khan, M. A. Siddiqui, Q. Saquib, J. Musarrat, A. A. Al-Khedhairy, Y. K. Mishra and B. A. Ali, RSC Adv., 2016, 6, 26111-26120.

41 R. Wahab, I. H. Hwang, Y. S. Kim, J. Musarrat, M. A. Siddiqui, H. K. Seo, S. K. Tripathy and H. S. Shin, Chem. Eng. J., 2011, 175, 450-457.

42 R. Wahab, Y. B. Yang, A. Umar, S. Singh, I. H. Hwang, H. S. Shin and Y. S. Kim, J. Biomed. Nanotechnol., 2012, 8(3), 424-431.

43 R. Wahab, S. Dwivedi, F. Khan, Y. K. Mishra, I. H. Hwang, H. S. Shin, J. Musarrat and A. A. Al-Khedhairy, Colloids Surf., B, 2014, 123, 664-672.
44 M. W. Pfaffl, Nucleic Acids Res., 2001, 29(9), e45.

45 International Conference on Harmonisation, Harmonized Tripartity Guideline, Validation of Analytical Procedures. Text and Methodology, Q2 (R1), 2005, November, https:// www.ich.Org.

46 P. Yanez-Sedeno, J. Riu, M. J. Pingarron and F. X. Rius, Trends Anal. Chem., 2010, 29(9), 939.

47 L. Chekli, B. Bayatsarmadi, R. Sekine, B. Sarkar, A. M. Shen, K. G. Scheckel, W. Skinner, R. Naidu, H. K. Shon, E. Lombi and E. Donner, Anal. Chim. Acta, 2016, 903, 13-35.

48 R. Wahab, F. Khan, Lutfullah, R. B. Singh, N. K. Kaushik, J. Ahmad, M. A. Siddiqui, Q. Saquib, B. A. Ali, S. T. Khan, J. Musarrat and A. A. Al-Khedhairy, Physica E Low Dimens. Syst. Nanostruct., 2015, 69, 101-108.

49 S. Ghosh, K. Das, K. Chakrabartia and S. K. De, Dalton Trans., 2013, 42, 3434-3446. 